\title{
The Significance of the Trope of the Belly in Silko's Ceremony
}

\author{
S. Bokir and E. Olmedo
}

\begin{abstract}
Leslie Marmon Silko has distinguished herself among storytellers who communicate and celebrate many Native American traditions with readers across the globe. Silko has been and continues to be fascinated by the ideas and legends of Native American culture. In her best novel to date, Ceremony, she follows Tayo, a troubled man, mixed raced halfwhite, half-Laguna, as he struggles to cope with post-traumatic stress syndrome of World War II. Silko uses wordplay and expressions to achieve and develop a unity of themes as well as complex emotions. Our research topic proposes to interrogate further Silko's both fascinating and important use of the word "belly" as trope in different parts in her novel and its different connotations within context, those different parts becoming increasingly connected creating more specific literary cohesion. Silko also discusses the role of the body as a corporeal theme in the practices of opposition, resistance and cultural creativity ( $c f$. the works of Jean and John Comaroff and Michel de Certeau). 'Leslie Silko's style, her powerful word choices and her strong cultural and ideological stances position her among the greatest writers of our time.
\end{abstract}

Index Terms-Belly, ceremony, conceptualization, Silko.

\section{INTRODUCTION}

As one of several important writers who have written about Native American experiences, culture and history, Leslie Marmon Silko mixes her style with the modern realities of the current society. She uses a number of myths and allegories from Native American traditions and connects them to the lives of people in the present. In her novel Ceremony, she specifically explores the lives and histories of Native American culture and society; she also explores intercultural relationships between Native Americans and other American ethnicities. In writing Ceremony, Silko proposes that the only solution for current problems in modern life is that people should go back to their origins and refine their relationships with nature. This is the only way to keep Native Americans connected with their humanity and to achieve harmony with others

Silko is fascinated with Native American traditions of storytelling, so much so that she narrated Ceremony in the form of stories to teach people what is important in this life and to enrich these stories with morals and values. Her book is notable for the repetition of certain symbolic words that gives her stories a wide range of interpretations and makes readers wonder if they have more meaning than the obvious. In this paper, I examine the symbolism of the term "belly"

Manuscript received September 23, 2015; revised December 13, 2015

The authors are with the National University of Malaysia UKM, Malaysia (e-mail: Shadabukier@tahoo.com). in Silko's Ceremony and explore the possible meanings this word has according to Silko's language and Native American traditions. This study will be done through the lenses of conceptualization metaphors through culture and language.

Sharifian defines conceptual metaphors as, "cognitive structures that allow us to conceptualize and understand one conceptual domain in terms of another. For instance, the English metaphorical expressions: 'heavy-hearted and lighthearted', reflect the conceptual metaphor of HEART AS THE SEAT OF EMOTION" [1]. Sharifian adds that there are certain kinds of conceptualizations that have a cultural root and are encrypted in and communicated through features of human languages. In this respect, Silko's novel conceptualizes the term "the belly" and encodes it through the Native American language and culture. The focus on meaning as conceptualization in Cultural Linguistics owes its significance to cognitive linguistics, a secondary discipline that Cultural Linguistics drew on at its establishment [1]. There has been much research that has investigated culturally constructed conceptual metaphors as their major concern; one example is Cultural Linguistics [2]. In the same way, Lakoff and Johnson (1980) declare that conceptual metaphors refer to the cognitive conceptualization of one term in relation to another. Ref. [3] In defining and explaining the concepts of conceptualization through culture and language, Sharifian found it very useful to illuminate the term cultural schema, as it has been theorized from the joint perceptions of a cultural group rather than being conceptualized from an individual's personal experiences.

Cultural cognition elaborates on the cultural experience that develops from the exchanges between individuals inside the cultural group [4]. Conceptualization is also defined as a collective cognitive method of categorization and schematization. Giving more descriptions to the term used in this definition, Rosch states that categorization is a "process by which distinct entities are treated as somehow equivalent." Ref. [5] So in a given society it became agreed upon certain terms carry more than one meaning. And at the same time, those meanings are used metaphorically to describe certain phenomena or to convey intense feelings. Glushko et al. (2008) write, "Categorization research focuses on the acquisition and use of categories shared by a culture and associated with language - what we will call 'cultural categorization'. Cultural categories exist for objects, events, settings, mental states, properties, relations and other components of experience" [6].

In Ceremony, Silko uses the word "belly" more than seventy times. She mentions the belly in different occasions and with different implications, especially suggesting that 
the belly is the core of things or the inner side of life and feelings. At the beginning of her novel, she mentions the Spider woman and her creation of everything by the spider web woven from her belly. It is the belly, which contains healing stories, and these stories will give salvation to both the white culture with all its materialism and the Native American culture with all its faces of evil represented in the novel by Emo.

\section{LOCATING THE STUDY}

In Native American religious traditions, as Daniel G. Brinton mentions in his book American Hero-Myths, there are many Native American myths and religious beliefs. He mentions the myth of the four Bacabas, which are called by Cogolludo the gods of winds:

Each was identified with a particular color and a certain cardinal point. The first was of the South. He was called Hobnil, the Belly; his color was yellow, which, as that of the ripe ears, was regarded as a favorable and promising hue; the augury of his year was propitious, and it was said about him, referring to some myth now lost, that he had never sinned as had his brothers [6].

It is very likely that Silko not only knows this myth but also uses it as the foundation of her novel. When Tayo sins by killing other human beings, he is said to be sick in his belly; the belly is an indicator of life and could not harmonize with the realities of killing or of destruction. The only way through which Tayo could be purified again and become human was through the vomiting and the discarding of the bad qualities he has imported into his core. Brinton continues to explain the indications of the term "belly" according to Native American myths. In his notes he writes that "Hobnil is the ordinary word for belly, stomach, from hobol, hollow. Figuratively, in these dialects it meant subsistence, life, as we use in both senses the word "vitals"" [7]. Similarly, there is other languages which use the same conceptualization of a term to mean certain things other that the agreed meaning; In the Persian language for instance, many Sufi scholars and poets uses the term Del, or nefs to mean things other than its original meaning. 'Del' 'the Heart' in Sufism is conceptualized "as the home of love or spirits." Ref. [1] Sharifian has mentioned on more than one occasion in his book the way Sufism associates Del with the personal self, emotions and ethics and values; however, "there are cases of the use of the word that tie 'del' more literally to the stomach or abdomen" [1]. This is in a way can be mirrored in the use of Silko to the term the belly as a sort of conceptualization of the word to mean other meaning as well. Sharifian has given many examples for the ways in which 'Del' is metaphorically used in Persian language and in the Sufi tradition, he continues, "a number of expressions in Persian associates 'del' with anxiety. Here it is clear that del refers to 'stomach' the fact that anxiety can lead to an upset stomach/abdomen" [1].

\section{HumORAL AND METAPHYSICAL FUnCTIONS}

In certain parts of the novel, Silko mentions the belly to indicate its more common reference as the central part of the body or the abdomen, which would include the stomach, the womb and other parts. However, there are additional meanings, allusions that open up deeper and wider ideas. Silko metaphorically conceptualizes the word "belly" as a person's deeper existence and his subconscious, which determines how he or she feels or behaves. Similarly, in the novel, the belly can be an indicator of people's true character, Sharifian says, "'Del' is conceptualized in Sufism as the source of patience. In the same way, the belly is conceptualized as well in Ceremony to mean the power of productivity and continuity; Silko refers to the belly as the womb, which can be extended to the relationship between the womb and birth, which moreover connects to continuity and traditions as well as the relationship to wisdom passed onto future generations through birth. The belly also represents the person's inner powers; it is not merely an organ in the human body, but rather a living thing to itself; it gives and creates human life. It is how the unborn child gets nutrients, and for Silko, it also nourishes the human soul through experiences one can grasp in the outside world.

In the first pages of Ceremony, we read the story of the old man as he is rubbing his own belly and says, "I keep them there/ here, put your hand on it/ See, it is moving. /There is life here/For the people" [8]. The old man's belly functions like a womb. Although he is not a woman, he can still produce life through the continuity of the traditions and the history. He carries all traditions and history as stories; stories are able to save people's lives and cure their illnesses. The old man keeps the stories in his belly, in the center of his being, the core of his existence, because it is something valuable and precious like an unborn child, which needs caring and protection, but which also later will produce new lives and new histories for this nation.

As Robert Nelson mentions in his book Leslie Marmon Silko's Ceremony: The Recovery of Tradition "in Keresan tradition, the idea that there is an anatomical relationship between stories and their tellers is not just metaphor. Silko touches on this relationship early in Ceremony" [9]. The stories in this old man's belly are both, a living being of its own as well as a source of life for others. It is a living being because it has existence, and spirit, it has actions in people's lives and it contains its own thoughts, morals, as well as, good and bad effects. It is, as well, nourished and nurtured by people's history and traditions, which are living things too; once people forget about these stories, these stories die, like any other human being who dies. Secondly, because in the core of any story there is some part that was real and some of its characters were once living people. These kind of stories are not told as fiction, they are told as history of land, time and of place; "Like everything else that moves and has power, a story properly understood is living thing and is thereby related to every other living thing" [9].

These stories give life to others by preserving history and heritage through generations. Silko makes it very clear that any individual cannot grow and develop without knowing his or her history first; this helps in developing a stronger connection with his society, and even more importantly, with his inner self. Tayo, the protagonist in Ceremony, has to go through a long journey of healing from all the effects of destruction and violence in the modern world. The only 
things that help him find himself are the stories of his ancestors; the tradition of his people saves him from being lost. He is healed when he finds his real self and when he is becomes in touch with humanity and nature again. What helped him were those stories which are preserved in the womb of humanity, and transferred to younger generations to give them life and health. Allan Chavkin comments that:

Within her story of Tayo's journey toward wholeness and health, Silko [...] conducts a healing ceremony for all of us, for the world at large. The implications are serious, not to be taken lightly. Self-reflexively, the life-giving story is within the belly of the storyteller while the rituals and ceremony from which the "he" voice arises are found within the belly of the story [10].

The stories Silko is telling us are not the stories of women or men; it is a collective effort of both as a community. And the roles overlap and reverse; the woman is the one who thinks about the story, while the man is the one who carries it, nurtures it and then passes it onto the upcoming generations through his belly. The woman here represents the power of wisdom and insight that people will be "telling the story she is thinking" [8], while the man is the symbol of survival, endurance and continuality.

The storyteller, being like a woman, carries the story in his belly, is able to create new life. Mary Chapman in her article "The belly of this Story" says that "language can engender life, because a story can "bear" a culture like a woman bears a child, and men through language, can have access to what might otherwise be considered a female power to create." Ref. [11] is exactly what helped Tayo heal. As Kristin Herzog writes in her article "Thinking Woman and Feeling Man," the suppression of a man's anima drives him insane, and this is exactly what happens to Tayo when he is forced to kill his fellow human beings. So the belly refers to the feminine side of the person, the part that keeps life and preserves it [12].

In the same way that the belly represents hope, life and reproduction, it also metaphorically conceptualized to mean human morality and subconscious; Sharifian writes, also in Persian, del is connected with personality treats, character and mood [1]. When Tayo becomes sick after the war, his belly is what troubles him. This can be clearly seen in the scene when he imagines that he has killed his uncle Josiah, and "he could not feel anything except a swelling in his belly, a great swollen grief that was pushing into his throat" [8]. The belly is the source of feelings here; he experiences the feeling of grief in his belly. It could be his subconscious, and his awareness of the outside world through his inner side. It is how he grasps and mixes his outside experiences with his inside qualities. When the outside world is not in harmony with his human qualities, his belly becomes upset, and he feels uncomfortable and sick.

The sickness in his belly continues and becomes worse as long as Tayo doesn't know how to deal with it, as long as he is ignorant of the reasons that make him sick and how to get rid of them: "He gagged as he pushed the door open, and something gave way in his belly. He vomited out everything he had drunk with them, and when that was gone, he was still kneeling on road beside the truck, holding his heaving belly, trying to vomit out everything — All the past, all his life" [8]. His sickness is in his belly; by vomiting he is trying to purge white culture's teachings, the killing and the violence he witnessed as well as participated in. $\mathrm{He}$ is rejecting all these forms of civilization. His belly, which represents his heritage, his origins and his culture, rejects all these forms of inhumanity he saw in the white culture. Matthew Teorey says that Tayo vomits because he "cannot digest a patriarchal outlook, choosing instead to nurture an unfamiliar 'organism' (a bigendered selfhood) that is developing in their belly (consciousness, soul, craw)" [13]. So if the vomiting is because his belly cannot grasp the Western society and the manly roles he has to adopt through violence and war, vomiting is the only way to get rid of these aspects that cause him to be sick.

The belly in Silko's Ceremony carries a variety of feelings; it is like a very sensitive meter that measures the human feelings. In the novel, Tayo perceives different emotions according to the situation. And each one affects his core, whether excitement, relief, fear or sadness; he feels that these feelings affect him so deeply to his belly. Silko describes how Tayo felt happy and comfortable when he became in harmony with nature, especially when "he smiled. Inside, his belly was smooth and soft, following the contours of the hills and holding the silence of the snow" [8]. Tayo has these feelings of relief because he begins at that point to understand things; he begins to figure out the realities around him about white men and Native Americans. That feeling of relief comforted him deep down into his belly. When Tayo encounters the same kind of feeling or maybe stronger, he becomes very excited by the thought that he will hand a note to the night Swan, and that affected his belly and made him "hear his heart beating and he was breathing fast; something was shaking in his belly" [8]. Not only Tayo's feelings are connected to his belly, but also his thoughts, his sexuality and desire go down to his belly. It is the center of all human feelings, and whenever there is a deeper experience of a feeling or a thought, it goes the whole way to his belly, the inner part of him as a human being.

His feeling of excitement goes deep inside him up to his belly. But the feelings that Tayo's encounters and affect him deeply are not only of happiness and excitements, but also those strong feelings that cause his belly to clench and ache. As when he is wandering alone in the desert, after losing his friends or who he thought were his friends, he felt lost and hurt; these feelings "hit him, in the belly, and spread to his chest in a single surge: he knew then that they were not his friends but had turned against him and the knowledge left him hollow and dry" [8]. The strong feeling of betrayal took over Tayo, and made him feel hollow and sad. Tayo's senses the entire world is in his belly, he is like a child who senses the outside world through his mouth, but instead Tayo's belly is affected by the outside world. Whenever he is happy or sad, nervous or excited, it hits him deep inside in his belly. When the cruel world of the white man struck him, it is his belly that gets ill; his belly could not handle all the crimes and the injustice of the modern world. His belly starts to regurgitate these unnatural conventions that he cannot assimilate in his pure humanity "he drank the beer slowly and waited to feel it spread from his belly, warming him all over" [8]. The belly is the center, the source from which every limb in him gets nurtured; it controls the spread 
of the beer and the warmth into his body; he is aware of that control and he is accepting it as a reality, as his existence.

\section{THE DISENCHANTMENT OF THE WORLD}

The conflict between Tayo and this chaotic world, which he can't assimilate or understand, is represented by his conflict with Emo. Tayo has always felt that he is an outsider, being raised by his Aunt, who is looking to him as a reminder of the family shame, someone who is not desired or welcome. He belongs to two different worlds, the white and the Indian, and at the same time, he belongs to neither. He does not understand himself as a mix, which makes it difficult for him to understand the world around him. The climax is his experience in the war, which troubles him more and overcomes him with doubts about everything. On the other hand, the war for the originally evil Emo, only emphasizes his qualities and gives him a way to express them. Emo represents the destructive powers of the world. The hatred and the damage that upsets the human being inside Tayo and, accordingly, upsets his belly the source of his feelings, his principles and the tie that relates Tayo to his ancestors. It is true that no one is evil for the sake of evil, and people always have motives for their bad behaviors, but with Emo, it is the point of view he holds regarding others, it is the same point of view of the destroyers, that they don't see people or life in anything, they only see objects, and they kill what they see. "Emo is a self-hating Native American and a sadist, and his willingness to reject compassion and generosity so as to be accepted into white society makes Tayo nauseous" [13]. The difference between Tayo and Emo, is not in the appearance or in the surface, it is in their bellies as well. This is why when Tayo wanted to attack Emo, he "jumped up and broke a beer bottle against the table; and before they could stop him, he shoved the jagged glass into Emo's belly" [8]. He did not aim at any other part of Emo's body except the belly. Tayo's aiming to the belly is not arbitrary, he knows that the belly is the source of the evilness that Emo has and spread on everybody. He thinks if he can stab him in the belly, it will be fatal, as it is the source of evil and the source of Emo's powers. Thinking of the belly in the way, Brinton mentions in his American Hero-myth, we will find that the belly is the source of Emo's powers and life, and it is the one, which takes the blame for Emo's sinful behavior [7].

Another difference between Tayo and Emo and their perception of life and the world is that Emo is using the white man's ways in treating the world and in treating his own self, while Tayo wants to go back to his ancestors, to his origins and to nature. As both Tayo and Emo witnessed the horrors of the war, Emo learned to hide his feelings and to run away from his fears and uncertainties. Emo and his friends use liquor to help them forget their pain, "Liquor was medicine for the anger that made them hurt, for the pain of the loss, medicine for tight bellies and choked-up throats. He was beginning to feel a comfortable place inside himself, close to his own beating heart, near his own warm belly" [8].

\section{CONCLUSION}

Tayo discovers more about Western culture, and how it differs from Native American culture. In Western culture, a man has to learn to forget his pain and his hurt through alcohol; it is like covering the wounds instead of treating them. But in Native American culture the treatment goes deep into the causes and cures them. Tayo feels the warmth in his belly because he is in good terms with his inner side, and he is in good terms with the outside natural world. He feels a harmony that flows gently between him and his surroundings. He doesn't feel the pain of being an outcast anymore. On the other hand, Emo's temporary warmth of the belly comes from alcohol, and the warmth comes from forgetting his identity and what he has done in the past. It is false warmth, which fades away quickly.

Tayo after the healing ceremony, when he begins to understand things better, he replaces the pain inside his belly with relief, and the pain of lost has been cured, "he was thinking about the medicine man had performed over him, testing it against the old feeling, the sick hollow in his belly formed by the memories of Rocky and Josiah" [8].

He overcomes his hollowness and his agony through going back to his ancestors' traditions and ceremonies. He becomes in touch with himself and with nature, unlike Emo who forgets his anger and pain through alcohol. Now, his belly is emptied from the horrific memories, it is filled by the experience he had with her (the night Swan) with new hopes, now memories of life rather than the memories of death. He is on his way to be cured of his sickness. The terror of the dreaming he had done in this bed was gone, uprooted from his belly; and the woman had filled the hollow spaces with new dreams [8].

In Ceremony, the connection with nature and with other humans is the way for a healthy self, "Josiah said that only humans had to endure anything, because only humans resisted what they saw outside themselves. Animals did not resist. But they persisted, because they became part of the wind. 'Inside, Tayo, inside the belly of the wind"' [8].

Animals are a part of nature. They don't kill unless hungry; they don't harm others for pleasure; they respect life and creatures, unlike human beings. Silko states that white people don't respect life; life becomes meaningless to them, and so too do other living creatures. Animals are in harmony with nature, and Tayo's belly is longing to be in harmony with nature too, as this is why Tayo is trying to feel with other living creatures, and having compassion towards them, feeling life in everything around him, in animals, in trees, in rivers and even in the wind.

Silko suggests that Tayo's healing journey represents what modern society must overcome. Native Americans as well as the Western society need to become more connected with its core, its innate self, in short, its belly. It should find better ways to look at others and to connect with nature. If all that happened, Western society will witness a sincere and deep healing from many problems. A connection with the past and its origins will create a stronger bond to the future.

\section{ACKNOWLEDGMENTS}

This research was supported by Sheikh Abdullah Boghshan. We thank our colleagues from Hadhramuot organization and Hadhramout University who provided insight and expertise that greatly assisted the research, 
although they may not agree with all of the interpretations/conclusions of this paper.

We thank Dr. James Ivory, Associate Professor in English Literature at Appalachian State University for assistance with the methodology and the structure of this research, and for comments that greatly improved the manuscript.

We would also like to show our gratitude to Dr. James Collins for sharing his pearls of wisdom with us during the course of this research, and we thank the reviewers for their so-called insights, we are immensely grateful for their comments on an earlier version of the manuscript, although any errors are our own and should not tarnish the reputations of these esteemed persons.

\section{REFERENCES}

[1] F. Sharifian, Cultural Conceptualizations and Language: Theoretical Framework and Applications, Amsterdam: John Benjamins Pub. Co. 2011, pp. 152-476.

[2] G. B. Palmer, Toward a Theory of Cultural Linguistics, Austin: U of Texas, 1996.

[3] G. Lakoff and M. Johnson, Metaphors We Live by, U of Chicago, 2008, p. 209.

[4] J. Goldstein, "Emergence as a construct: History and issues," Emergence: Complexity and Organization, vol. 1, no. 1, pp. 49-103, 1999.

[5] E. Rosch, "Principles of categorization," in Cognition and Categorization, E. Rosch and B. B. LIoyd, Eds. Hillsdale NJ: Lawrence Erlbaum, 1978, p. 6.

[6] R. J. Glushko, P. P. Maglio, T. Matlock, and L. W. Barsalou, "Categorization in the Wild," Trends in Cognitive Science, vol. 12, no. 4 , pp. $129-135$.

[7] D. Brinton, American Hero-Myths: A Study in the Native Religions of the Western Continent, Middlesex: Echo Library, p.152.

[8] L. M. Silko, Ceremony, New York: Penguin Books, 2006, pp. 2-225.
[9] R. M. Nelson, Leslie Marmon Silko's Ceremony: The Recovery of Tradition, New York: Peter Lang, 2008, p. 22.

[10] A. Chavkin, Leslie Marmon Silko's Ceremony: A Casebook, Oxford: Oxford Univ. Press, 2002, p. 94.

[11] M. Chapman, "The belly of this story: Storytelling and symbolic birth in native American fiction," Studies in American Indian Literature, vol. 7, no. 2, p. 10, Summer 1995.

[12] K. Herzog, "Thinking woman and feeling man: Gender in Silko's Ceremony," Melus, pp. 25-36.

[13] M. Teorey, "Spinning a bigendered identity in Silko's Ceremony and Puig's Kiss of the Spider Woman," Comparative Literature Studies, vol. 47, no. 1, pp. 1-20, 2010.

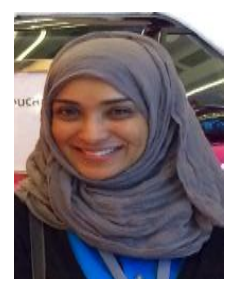

Shada Bokir was born in Aden, Yemen, she is currently a doctorate candidate. The topic of her PhD dissertation is "The ideology of social taboos on women in controversial Yemeni texts". Ms. Bokir was working as a university lecturer at Hadhramout University, Yemen until she was awarded the Fulbright scholarship to the United States of America in 2009; she earned her master's degree in English literature at Appalachian State University in 2011. Her master's thesis was "A comparative study between Arab writers and Arab western writers in the theme of intercultural love". Her area of interest is sociocultural anthropology and women studies especially in the Middle East and Yemen. She mainly focuses on the impact of the Yemeni literature and photography in conveying the sociocultural structure in the Yemeni society. Ms. Bokir was awarded a scholarship to Malaysia in 2013. She is currently doing her PhD degree in English literature at the National University of Malaysia (Universiti Kebangsaan Malaysia).

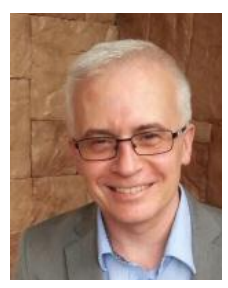

Eric Olmedo is a senior research fellow at the Institute of Ethnic Studies, KITA, the National University of Malaysia (Univeristi Kembangsaan Malaysia). He holds two master degrees, one is in sociology of organizations, and another in hospitality and tourism management, he also received a $\mathrm{PhD}$ degree in sociology. His research interests revolve around sociology of work, food anthropology and anthropotechnology. 